\title{
The effects of socio-demographic factors and work-life balance on employees' emotional exhaustion ${ }^{1}$
}

\author{
Türker Tuğsal $^{2}$
}

\begin{abstract}
The object of the research is observing the effects of socio-demographic factors and work-life balance on employees' emotional exhaustion. The sample of the research consists of 261 participants in retailing, education, service, industry and logistics sectors. In line with the theoretical background, proper methods that are hierarchical regression analysis and analysis of variance (ANOVA) are implemented. The contribution of the research to the existing literature is exploring the relationship between socio-demographic factors, work-life balance and burnout by carrying out the implementation in organizations. Findings of the research demonstrate that the predictor with the highest effect on emotional exhaustion is the variable named taking time for oneself. The predictor with the lowest effect is variable named life is just working. Briefly we can say, it could be argued that emotional exhaustion declines by .398 units should taking time for oneself increases 1 unit. Emotional exhaustion decreases by .223 units whether work-life accordance is changed by 1 unit. Emotional exhaustion drops 196 units should life is just working increases 1 unit. By contrast, when you change neglecting life 1 unit, emotional exhaustion decreases by .202 units. Should carrying work to home changes 1 unit, emotional exhaustion increases by .313 units. To sum up, regarding to marital status, monthly total income and sector; there are significant differences between the groups in the levels of emotional exhaustion of employees. It appears that there is no significant difference between other groups.
\end{abstract}

Keywords: Work-life balance; emotional exhaustion; socio-demographic factors; hierarchical regression; ANOVA.

\section{Introduction}

Over the past 30 years there has been a significant increase in the field of work-life balance and burnout. Undoubtedly, this increase is almost certainly due to the change of work's structure. Most studies in the literature have focused on work-life balance and burnout relationship (Chiang, Birtch \& Kwan, 2010; Chimote \& Srivastava, 2013; Karabacak, 2013; Pichler, 2009). These studies are frequently implemented in the field of education, health and defense; and the participants are mostly nurses (Altay, Gönener \& Demirkıran, 2010; Li, Ruan \& Yuan, 2015); teachers (Avanzi, Schuh, Fraccaroli \& Dick, 2015; Khezerlou, 2013; Otacioğlu, 2008); academicians (Budak \& Sürgevil, 2005; Moeller \& Chung-Yan, 2013) and police officers (Novara, Garro \& Di Rienzo, 2015). By contrast, it is a widely held view that a small number of studies which have focused on the relationship between work-life balance, emotional exhaustion and socio-demographic factors; moreover, only a small number of them have been carried out in the organizations. Therefore, this study aims to fill this gap by carrying out the implementation in organizations and observe the relationship between socio-demographic factors, work-life balance and burnout. The following sections of

\footnotetext{
1 Derived from doctoral dissertation.

${ }^{2}$ Research Assistant, Beykent University, School of Applied Sciences, Department of Financial Markets and Portfolio Management, t.turker@gmail.com
} 
Tuğsal, T. (2017). The effects of socio-demographic factors and work-life balance on employees' emotional exhaustion. Journal of Human Sciences, 14(1), 653-665. doi:10.14687/jhs.v14i1.4383

the research proceed as follows. In the second part, in order to link work-life balance with emotional exhaustion, theoretical background is briefly outlined. The third part of the research considers the methodology and research findings. After discussion section, the final level of the research consists of conclusion.

\section{Theoretical Framework and Review of the Literature}

The second part of the research consists of the definitions and literature review of the work-life balance and emotional exhaustion. It is necessary here to clarify that there are numerous terms that are used to describe work-life balance and emotional exhaustion. Besides; according to the existing literature, socio-demographic factors in this research are determined as gender, age, marital status, education, number of children, total monthly income, sector, department and working hours.

\subsection{Work-Life Balance}

Work can simply be defined as paid employment; besides, life can be loosely described as non-work activities. On the question of balance, it has been used to refer to situations in which role conflict at work and home is at the lowest level (Clark, 2000). The term life as a variable encompasses (1) unworked time, (2) enjoying facilities that one desire to do at home, (3) spend time with spouse or family, and (4) family responsibilities (Pichler, 2009, p. 461).

Although differences of opinion stil exist, there appears to be some agreement that life is far from conflict (Friedman, Christensen \& Degroot, 1998). More recently, a further definition is given by Noon \& Blyton (2007, p. 356) who describe work-life balance as the ability to maintain one's work and non-work lives successfully but at the meantime without harming the experience of someone else's satisfaction.

It seems that most studies in the field of work-life balance occasionally have focused on organizational performance (Beauregard \& Henry, 2009); burnout and work stress relationship (Barrett, Mazerolle \& Eason, 2016; Karabacak, 2013) and demographic factors (Adriaenssens, De Gucht \& Maes, 2015; Anila \& Krishnaveni, 2016; Padmasiri \& Mahalekamge, 2016; Panisoara \& Serban, 2013; Pichler, 2009).

According to the researchers in the literature it could be said that there is a plausible link between work-life balance and working time, flexibility, employment and unemployment, welfare, social security, family, migration, birth, demographic changes, consumption, rest time and leisure time (Dex \& Bond, 2005, cited in Pichler, 2009; MacInnes, 2006; Smithson \& Stokoe, 2005).

According to explanatory studies aimed at determining the variables that predict work-life balance, these variables are listed as; personal characteristics, values, occupation, working hours, working conditions, child and elderly care, housework and tasks, cleaning, rest time and leisure time (Crooker, Smith \& Tabak, 2002; Noor, 2003; Pichler, 2009).

As far as Guest (2002, p. 265) is concerned personal factors that predict the work-life balance are listed as follows: energy, personal control and coping, gender, age and personality. On the other hand, in spite of Guest's (2002) findings about gender and age, it is argued that gender and age are not found robust enough to explain work-life balance and burnout (Keeton, Fenner, Johnson \& Hayward, 2007). With regard to effects of work-life balance, research results of UmeneNakano et al. (2013) points out that employees who experience difficulties in work-life balance have emotional exhaustion and depersonalization at higher levels. Besides, Maxwell \& McDougall (2004, p. 381) hold the view that the organizational benefits of work-life balance are listed as (1) the decrease in the absence of employees, (2) increase in the quality of service, and (3) increase in organizational commitment. 
Tuğsal, T. (2017). The effects of socio-demographic factors and work-life balance on employees' emotional exhaustion. Journal of Human Sciences, 14(1), 653-665. doi:10.14687/jhs.v14i1.4383

\section{2. Emotional Exhaustion}

In the present research, the term emotional exhaustion has been used to refer to the emotional and cognitive distance between one's job to cope with overwork. It is necessary here to clarify exactly what is meant by emotional exhaustion is that it is a both subscale and a dimension of burnout (Maslach, Schaufeli \& Leiter, 2001). Therefore, it should be evaluated in this way. According to Shirom (1989, p. 33) emotional exhaustion is one of the components of burnout.

In terms of factors that could cause emotional exhaustion, it has commonly been assumed that personal and socio-demographic factors can give rise to emotional exhaustion. Although differences of opinion still exist, there appears to be some agreement that personal factors refers to personal characteristics of individuals who experience emotional exhaustion. Personal factors include demographic variables such as age, gender, marital status and education; moreover, personality traits and work-related behaviors.

Numerous pioneering studies (Constable \& Russell, 1986; Etzion, 1984; Kutsal \& Bilge, 2012; Panisoara \& Serban, 2013; Pichler, 2009) which observe the linkage between sociodemographic factors like age, gender, marital status, work experience and burnout; contribute to the literature by explaining the burnout differences between employees. According to Dillon \& Tanner (1995) and more recently Yildirım (2008) it might be said that gender, age and marital status have not linkage with burnout. However, in contrast to these researchers Jackson (1993) and Cordes \& Dougherty (1993) claim that there is a plausible link between these variables.

According to Gülalp, Karcıoğlu, Sarı \& Köseoğlu (2008) there is lack of adequate linkage between marital status and burnout. By contrast, Ifeagwazi (2006) claims that married employees' burnout levels are significantly lower than single employees' burnout levels. Furthermore, Norlund et al. (2010) point out that burnout tendency of women is higher than men. Besides, Purvanova \& Muros (2010) in their thorough study state that emotional exhaustion tendency is higher in women whilst depersonalization tendency is higher in men. Thus far, this section has attempted to provide a brief summary of the theoretical background relating to work-life balance and emotional exhaustion. The next chapter describes the procedures and methods used in this research.

\section{Methodology and Research Model}

The following part of the research moves on to describe in greater detail of the methodology and research model. In the case of the methodology, this topic can best be treated under four headings: (1) research sample, (2) reliability and factor analysis of the scales, (3) hierarchical regression analysis and research findings, and (4) analysis of variance (ANOVA) and findings.

In line with the theoretical framework (Constable \& Russell, 1986; Ross, Altmaier \& Russell, 1989; Sencan, 2007, p. 118) for research model is thought to be a comparison model with hierarchical regression analysis. A comparison is made in the model of the research. Since there is no universal measuring instrument (such as measuring length with meter) in the measurement of the variables, the values of the variables are being compared in the study.

The comparison model is illustrated below. $b_{0}, a_{1}, \ldots, a_{n}$ are the constants. $a_{1}, a_{2}, \ldots, a_{n}$ represent the slopes of the regression lines. In Figure 1 it is seen that two dimensional visualization of $n$ dimensional space where all independent variables are kept constant except one of them.

Dependent Variable $=\mathrm{b}_{0}+\mathrm{a}_{1} \mathrm{x}_{1}+\ldots .+\mathrm{a}_{\mathrm{n}} \mathrm{x}_{\mathrm{n}}$ 
Tuğsal, T. (2017). The effects of socio-demographic factors and work-life balance on employees' emotional exhaustion. Journal of Human Sciences, 14(1), 653-665. doi:10.14687/jhs.v14i1.4383

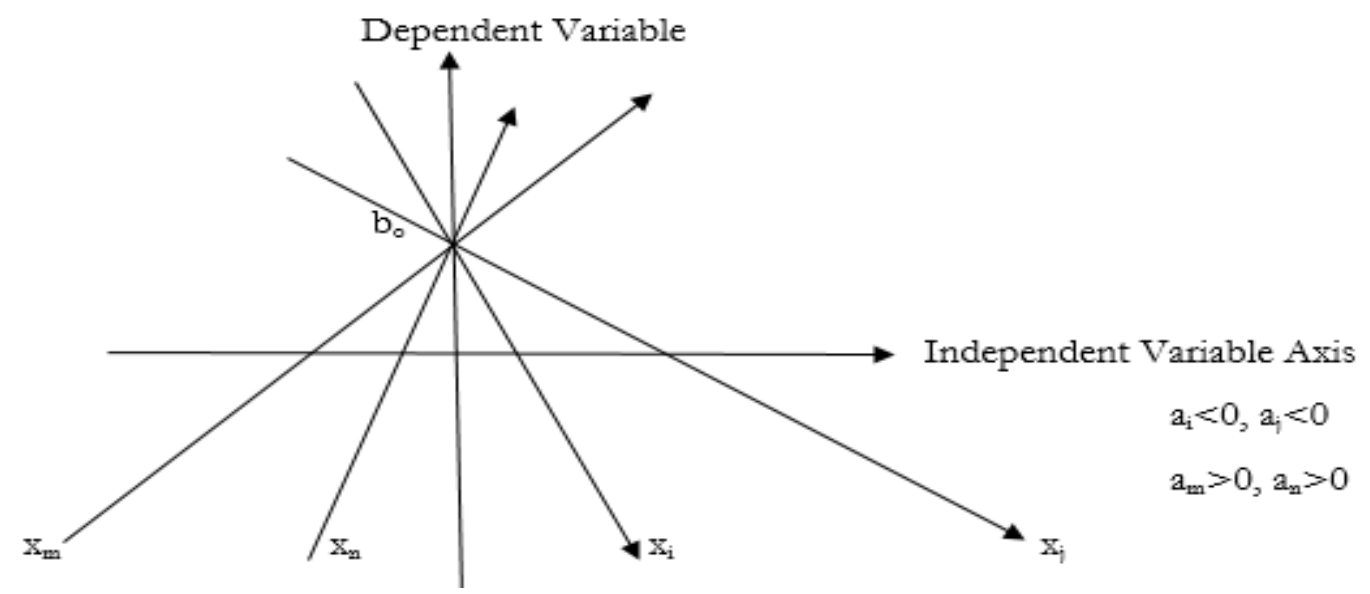

Figure 1. Comparison Model on Regression Equation

a $>0$ : Dependent variable and independent variable change in the same way. Independent variable's effect is in the dependent variable's increasing direction, else if;

$a<0$ : Independent variable changes on the inverse direction of dependent variable. Independent variable's effect is in the dependent variable's decreasing direction. than that of $x_{j}$.

If $\left|a_{i}\right|>\left|a_{j}\right|$ and $a_{i}<a_{j} ; a_{n}>a_{m}$ then; the effect of $x_{i}$ variable on dependent variable is greater

The slope of each line represents a measure for the impact of independent variable on the dependent variable. When independent variable increases, dependent variable also changes. Therefore, the greater the slope, the greater the effect is.

If $\mathrm{a}<0$, the direction of the effect is decreasing; if $\mathrm{a}>0$ the direction of the effect is increasing.

If the absolute value of $a_{n}, a_{m}, a_{i}, a_{j}$ in the model is the highest; it can be said that it is the one, independent variable which mostly affects the model.

\subsection{Research Sample}

As was pointed out in the introduction to this paper, in this section findings and interpretations that arise as a result of analyzing collected data have been explained. In the multiple regression analysis used in the research, it is necessary to have a sample size, at least 10-15 measurements or data for each prediction variable in the model (Field, 2013, p. 222). There are totally 6 predictive variables; five in six are in the work-life balance scale and one variable in the emotional exhaustion scale. Therefore, approximately $15 \times 6=90$ measurements are required. It is thought that 261 data sets are sufficient.

The online questionnaire is conducted among employees in Istanbul via random sampling method. The research is carried out in 5 sectors and 80 of the participants $(30.65 \%)$ are employed in the retailing sector, 64 participants $(24.52 \%)$ are employed in the education sector, 64 participants $(24.52 \%)$ are employed in the service sector, 31 participants $(11.88 \%)$ are employed in industry sector and 22 participants $(8.43 \%)$ are logistics sector employees.

Frequency and percentage distributions of personal information of employees contributing to the survey are as follows. It appears that $123(47.13 \%)$ of the employees participated in the survey are female and 135 participants $(51.72 \%)$ are male. 101 people $(38.70 \%)$ are in the age range of $18-29$ years, 88 employees $(33.72 \%)$ are in the age range of $30-39$ years, 53 employees $(20.31 \%)$ are in the age range of 40-55 years and 18 employees $(6.90 \%)$ are 56 years and older. $45.21 \%(118 \mathrm{em}$ ployees) of the employees are single and 51.34\% (134 employees) are married. While 9 employees 
Tuğsal, T. (2017). The effects of socio-demographic factors and work-life balance on employees' emotional exhaustion. Journal of Human Sciences, 14(1), 653-665. doi:10.14687/jhs.v14i1.4383

$(3.45 \%)$ expressed that they were divorced, there are no employees whose husband or wife was dead. With regard to the monthly total income level, 15.33\% (40 employees) of the employees' income level is between $0-1,500 \mathrm{TL}$ which represents approximately minimum wage. Moreover, $31.80 \%$ (83 employees) employees' income level is between 1.501-3.000TL, 25.67\% (67 employees) employees' income level is between 3.001-5.000 TL and the income of $26.82 \%$ (70 employees) is over 5,001TL.

\subsection{Reliability and Factor Analysis of the Scales}

In the research, reliability analysis is performed separately for two scales related to two concepts that are the subject of the research. Reliability analysis of the work-life balance scale (Apaydin, 2011) and the reliability analysis of the Turkish version (Ergin, 1992) of Maslach \& Jackson's (1986) burnout scale is implemented. The emotional exhaustion subscale in Maslach \& Jackson's (1986) burnout scale is used in the measurement of emotional exhaustion and reliability analysis of emotional exhaustion scale is also done.

Table 1. Reliability Statistics of Scales

\begin{tabular}{lcc}
\hline & Cronbach's Alpha & $\begin{array}{c}\text { Cronbach's Alpha Based on } \\
\text { Standardized Items }\end{array}$ \\
\hline Work-Life Balance Scale & .888 & .885 \\
\hline Emotional Exhaustion Scale & .933 & .927 \\
\hline
\end{tabular}

As a result of the reliability analysis of the work-life balance scale, Cronbach's Alpha value is calculated as .888. Similarly, as a consequence of the reliability analysis of the emotional exhaustion scale, Cronbach's Alpha value is measured as .933 . Therefore, it can be said that the reliability of both scales is high.

In terms of scales' factor loadings and explanatory factor analysis, due to the fact that worklife balance scale could not be explained with single factor on confirmatory factor analysis; performing an explanatory factor analysis is required. Furthermore, in order to apply factor analysis, the result of the Bartlett Sphericity test should be significant $(\mathrm{p}<.05)$ (İslamoğlu \& Alnıaçık, 2014, p. 396).

Table 2.KMO Sample Adequacy and Bartlett Sphericity Tests Statistics of Work-Life Balance Scale

\begin{tabular}{cccc}
\hline KMO Sample Adequacy & Bartlett Sphericity & $\mathrm{R}^{2}$ & $\mathrm{p}$ \\
\hline .903 & 435 & $\% 56.97$ & $\mathrm{p}<.001$ \\
\hline
\end{tabular}

Keiser-Meyer-Olkin sample adequacy value of the scale is .903. The Bartlett Sphericity test value is 435 and the model is significant at $\mathrm{p}<.001$ significance level. As a result of exploratory factor analysis, varimax rotation technique is applied and explained with 5 factors in this research. These factors are named neglecting life, life is just working, work-life accordance, taking time for oneself and carrying work to home. The reported cumulative variance of the scale is $56.97 \%$.

Hereby, it is necessary at the moment to clarify exactly what is meant by exploratory factors which are neglecting life, life is just working, work-life accordance, taking time for oneself and carrying work to home. In this research the term neglecting life will be used to describe phenomenon that someone think that the situation does not reflect the ideal life style and think that $\mathrm{s} /$ he is missing many things in the life. The term life is just working has been used to refer to the situations in which one keeps working on the weekends continuously, usually goes out late at work, misses activities out of work, sacrifices basic vital activities like sleeping and nutrition. The term work-life ac- 
Tuğsal, T. (2017). The effects of socio-demographic factors and work-life balance on employees' emotional exhaustion. Journal of Human Sciences, 14(1), 653-665. doi:10.14687/jhs.v14i1.4383

cordance can broadly be defined as it is the ability that one can decide the priorities; plan life, duties and works; manage workload, take time for hobbies, can seperate time to work and life appropriately and can establish a balance between work and personal life. There is a degree on uncertainty around the terminology in defining taking time for oneself; however, it could be loosely described as having difficulty at work because of sacrifice in private life, making unhealthy decisions about which tasks one should give time and energy and being interested in personal problems at work. Finally, the term carrying work to home is used here to refer to the situations that one also works at home; even though work is overtime, person thinks of work at home, therefore s/he mentally works.

\subsection{Hierarchical Regression Analysis and Research Findings}

The data of the study are evaluated by hierarchical regression analysis from multiple regression analysis models. Analysis and model calculations are applied with SPSS 20.0 software.

The effects of dimensions of work-life balance that are namely; neglecting life, living just for working, work-life accordance, taking time for oneself, carrying work to home and sociodemographic factors on emotional exhaustion of employees are analyzed by hierarchical regression analysis. Findings related to the analysis are as follows. With the first step of regression analysis in this model, the relationship between emotional exhaustion and socio-demographic variables (monthly total income, gender, working hours, department, sector, marital status, education, number of children and age) is examined. Durbin-Watson value is calculated as 2.137 in the model and it might be interpreted that there is no problem in the model.

Table 3. Model Summary Table of Effects on Emotional Exhaustion

\begin{tabular}{|c|c|c|c|c|c|c|c|}
\hline \multirow{2}{*}{ Step } & \multirow{2}{*}{$\mathrm{R}$} & \multirow{2}{*}{$\mathrm{R}^{2}$} & \multirow{2}{*}{ Adjusted $\mathrm{R}^{2}$} & \multicolumn{3}{|c|}{ Change Statistics } & \multirow{2}{*}{$\begin{array}{c}\text { Durbin- } \\
\text { Watson Value }\end{array}$} \\
\hline & & & & $\mathrm{R}^{2}$ Change & F Change & $p$ & \\
\hline 1 & .377 & .142 & .102 & .142 & 3.569 & .000 & \\
\hline 2 & .655 & .429 & .389 & .287 & 23.299 & .000 & 2.137 \\
\hline
\end{tabular}

As predictor variables for hierarchical regression analysis; work experience, education, number of children, age variables explain the variance significantly. The results of the analysis are as follows; at the first step, socio-demographic factors explained $14.2 \%$ of the variance $(\mathrm{p}<.001)$. In the second phase, dimensions of work-life balance which are neglecting life, life is just working, work-life accordance, taking time for oneself, carrying work to home are included in the model and accounted for $42.9 \%$ of variance $(\mathrm{p}<.001)$. This ratio implies that the power of explanation of variance is high (Pichler, 2009, p.460). The adjusted $\mathrm{R}^{2}$ is calculated as .389 with the estimation variables included in the second stage of the study. The difference between the $\mathrm{R}^{2}$ value and the adjusted $\mathrm{R}^{2}$ value is $.429-.389=.04$ (about 4\%). In this context, if the second model had been created at the population instead of the sample; it could be argued that the result will be explained with a variance of about $4 \%$ lower. To put it clear, the result will have explained $38.9 \%$ of the total variance.

Table 4. ANOVA Statistical Values Table of Effects on Emotional Exhaustion

\begin{tabular}{clcccc}
\hline Step & & $\begin{array}{c}\text { Sum of } \\
\text { Squares }\end{array}$ & Mean Square & F & $\mathrm{p}$ \\
\hline \multirow{2}{*}{1} & Regression Value & 35.197 & 3.200 & 3.569 & .000 \\
& Residual Value & 212.494 & .897 & & \\
& Total & 247.692 & & & \\
& Regression Value & 106.230 & 6.639 & 10.889 & .000 \\
2 & Residual Value & 141.461 & .610 & & \\
& Total & 247.692 & & & \\
\hline
\end{tabular}


Tuğsal, T. (2017). The effects of socio-demographic factors and work-life balance on employees' emotional exhaustion. Journal of Human Sciences, 14(1), 653-665. doi:10.14687/jhs.v14i1.4383

In the ANOVA table, $\mathrm{F}$ values are statistically significant at $\mathrm{p}<.001$ level in both steps. Therefore, instead of using average values; for the best prediction, it could be recommended to use models. However, model in the second step should be preferred in order to explain better since the F-value is increasing and statistically significant. In this context; it is seen that the estimation power is significant in the first stage $(\mathrm{F}=3.569)$. However, in the second stage, the $\mathrm{F}$ value increases with the estimation variables added to the model $(\mathrm{F}=10.889)$. The prediction power is higher and the significance is higher $(\mathrm{p}<.001)$.

The model summary and ANOVA values are statistically significant and it is seen that tolerance and Variance Inflation Factor values are appropriate in the second preferred model.

Table 5. Statistical Values of Estimation Variables with Affect on Emotional Exhaustion

\begin{tabular}{llllll}
\hline & & B & SE & Beta & p \\
\hline Step 1 & & & & \\
& Constant (Emotional Exhaustion) & .311 & .407 & & \\
& Marital Status & .276 & .106 & .189 & .010 \\
& Work Experience & .211 & .086 & .227 & .015 \\
Step 2 & & & & \\
& Constant (Emotional Exhaustion) & -.011 & .358 & & \\
& Neglecting Life & -.202 & .054 & -.200 & .000 \\
& Life is Just Working & -.196 & .062 & -.195 & .002 \\
& Work-Life Accordance & -.223 & .052 & -.223 & .000 \\
& Taking Time for Oneself & -.398 & .055 & -.399 & .000 \\
& Carrying Work to Home & .313 & .056 & .315 & .000 \\
\hline
\end{tabular}

* For Step $1 \mathrm{R}^{2}=.142(\mathrm{p}<.001) ;$ For Step $2 \mathrm{R}^{2}=.429(\mathrm{p}<.001) ; \Delta \mathrm{R}^{2}=.287$

In terms of statistical calculations, the regression equation of the second model could be expressed as:

Emotional Exhaustion= $-.011+[(-.202 x$ Neglecting Life $)+(-.196 x$ Life is Just Working $)+(-$ $.223 x$ Work-Life Accordance) $+(-.398 x$ Taking Time for Oneself $)+(.313 \times$ Carrying Work to Home $)]$ 
Tuğsal, T. (2017). The effects of socio-demographic factors and work-life balance on employees' emotional exhaustion. Journal of Human Sciences, 14(1), 653-665. doi:10.14687/jhs.v14i1.4383

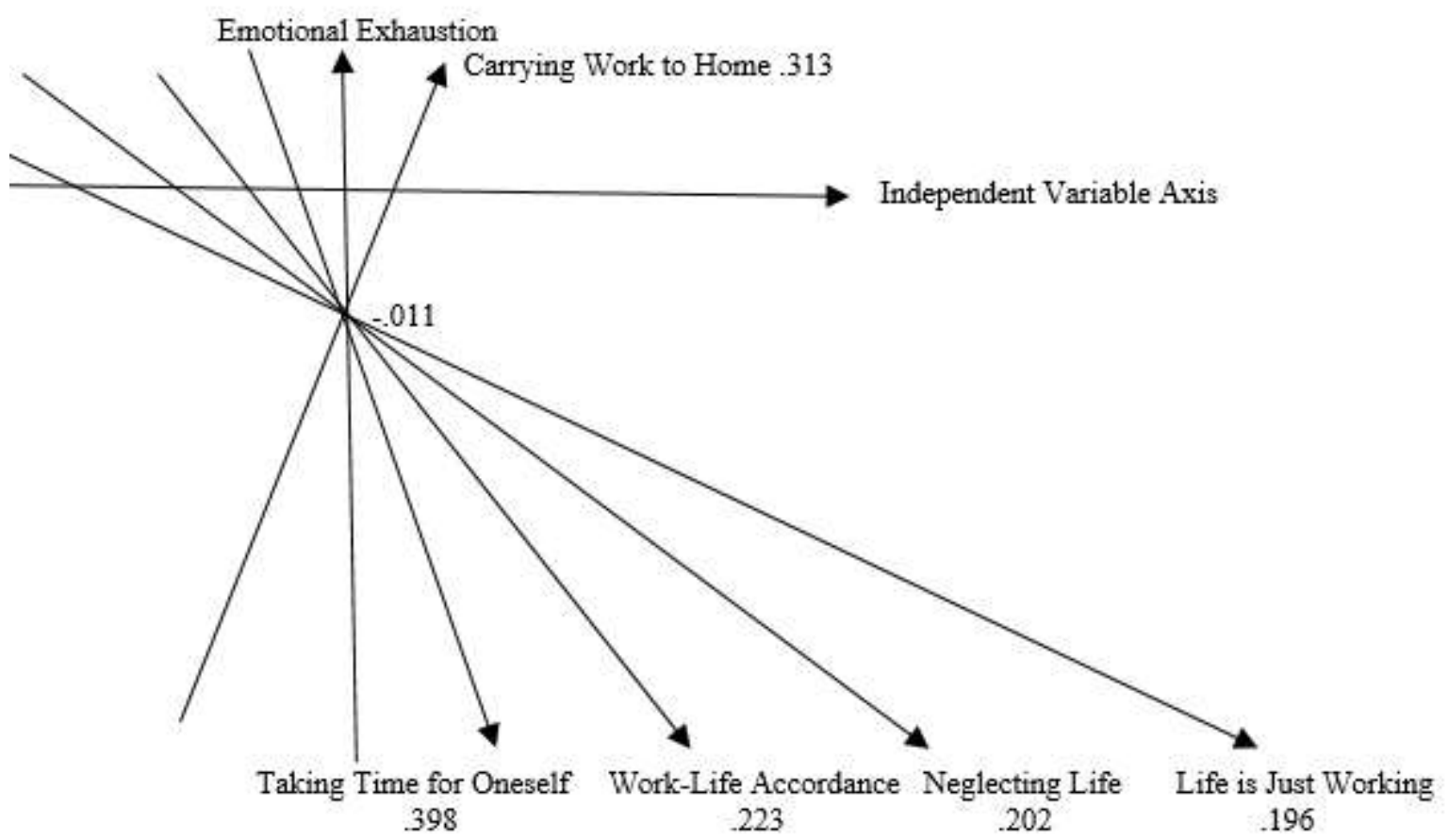

Figure 2. The Effectiveness and Direction of Independent Variables on Emotional Exhaustion

The regression equation shows how much each prediction variable explains the dependent variable when the effect of all other estimation variables is kept constant. Neglecting life has negative effect at level of 202 on emotional exhaustion; life is just working has negative effect at level of .196 on emotional exhaustion; work-life accordance has negative effect at level of .223; taking time for oneself has negative effect at level of .398 on emotional exhaustion; on the contrast, carrying work to bome has positive effect at level of .313 on emotional exhaustion.

Table 6. Impact and Direction of Independent Variables on Emotional Exhaustion

\begin{tabular}{lcc}
\hline Independent Variable & Effect Intensity & Effect Direction \\
\hline Taking Time for Oneself & .398 & - \\
Carrying Work to Home & .313 & + \\
Work-Life Accordance & .223 & - \\
Neglecting Life & .202 & - \\
Life is Just Working & .196 & - \\
\hline
\end{tabular}

The variable with the highest effect on emotional exhaustion is the taking time for oneself variable. The variable with the lowest effect is that life is just working variable. Emotional exhaustion declines by .398 units when taking time for oneself increases 1 unit. Emotional exhaustion decreases by .223 units when work-life accordance is changed by 1 unit. Emotional exhaustion drops 196 units when life is just working increases 1 unit. When you change neglecting life 1 unit, emotional exhaustion decreases by .202 units. On the contrary, when carrying work to home changes 1 unit, emotional exhaustion increases by .313 units.

\subsection{Analysis of Variance (ANOVA) and Findings}

It is argued that the factors which affect the burnout of the employees are demographic variables such as age, gender, marital status and education, personality traits, and work-related behavioral patterns. In some studies, it has been found that the burnout level of women is high; on the contrast, the burnout level of men is high in some studies whereas there are also nondifferential investigations. Regarding to researches on marital status; it appears that unmarried peo- 
Tuğsal, T. (2017). The effects of socio-demographic factors and work-life balance on employees' emotional exhaustion. Journal of Human Sciences, 14(1), 653-665. doi:10.14687/jhs.v14i1.4383

ple have a higher burnout tendency with comparison to married people (Maslach, Schaufeli \& Leiter, 2001).

\subsubsection{Differences in Levels of Emotional Exhaustion of Employees by Marital Status}

According to marital status, there is a significant difference between the groups in the levels of emotional exhaustion of employees ( $\mathrm{p}>$.05).

Table 7. Differences in Emotional Exhaustion Levels of Employees by Marital Status

\begin{tabular}{cccccc}
\hline & Marital Status & Marital Status & Average Difference & SE & $\mathrm{p}$ \\
\hline \multirow{2}{*}{ Emotional Exhaustion } & \multirow{2}{*}{ Married } & Single & -.4192 & .1240 & .002 \\
& & Divorced & -.6791 & .3371 & .111 \\
\hline
\end{tabular}

Although there are studies that state married employees have higher levels of emotional exhaustion than married employees (Ross, Altmaier \& Russell, 1989); there are also studies of burnout indicating that married employees feel less stress and burnout. Ross, Altmaier \& Russell (1989) argue that this situation about increases in burnout, may result from the role multiplicity. Maslach \& Jackson (1981) argue that marital status is only related to emotional exhaustion.

It could be argued that the research findings are inconsistent with recent research findings of Ross, Altmaier \& Russell (1989). Table 7 shows that marital status has an effect on the emotional exhaustion. According to the result of the Tukey test that is applied to determine the difference between the marital status of the employees, the level of emotional exhaustion of married employees is lower than the emotional exhaustion level of single employees by .4192 and the difference is statistically significant $(\mathrm{p}=.002)$. On the other hand, there was no significant difference between the levels of emotional exhaustion of married employees and divorced employees $(p=.111)$.

3.4.2. Differences in Levels of Emotional Exhaustion of Employees by Monthly Total Income

According to the findings in Table 8; it appears that monthly total income level has an effect on emotional exhaustion.

Table 8. Differences in Emotional Exhaustion Levels of Employees by Monthly Total Income

\begin{tabular}{lccccc}
\hline & $\begin{array}{c}\text { Monthly Total } \\
\text { Income }\end{array}$ & $\begin{array}{c}\text { Monthly Total } \\
\text { Income }\end{array}$ & $\begin{array}{c}\text { Average } \\
\text { Difference }\end{array}$ & SE & $\mathrm{p}$ \\
\hline \multirow{2}{*}{ Emotional } & & 1,501TL-3,000TL & .4882 & .2190 & .126 \\
Exhaustion & $0-1,500 \mathrm{TL}$ & 3,001TL-5,000TL & .5969 & .2153 & .036 \\
& & 5,001TL or more & .7196 & .2240 & .011 \\
\hline
\end{tabular}

According to the results of the Games-Howell test that is applied to determine the emotional exhaustion, it is seen that there is a significant difference $(p<.05)$ between employees who have a monthly total income of $0-1,500 \mathrm{TL}$ and those who have a monthly total income of 3,001TL5,000TL and those of 5,001TL or more. Therefore; emotional exhaustion levels of employees with a monthly total income of 0-1,500 TL are higher by .7196 unit than those of employees with a monthly income of 5,001TL and more. Furthermore; emotional exhaustion levels of employees with a monthly total income of $0-1,500$ TL are higher by .5969 unit than those of employees with a monthly income of 3,001-5,000TL ( $\mathrm{p}<.05)$.

\subsubsection{Differences in Levels of Emotional Exhaustion of Employees by Sector}

According to Schaufeli \& Enzmann (1998), teachers are found to have the highest level of emotional exhaustion. Emotional exhaustion is moderate in those working in social work and health; however, emotional exhaustion level of mental health workers and high school teachers is 
Tuğsal, T. (2017). The effects of socio-demographic factors and work-life balance on employees' emotional exhaustion. Journal of Human Sciences, 14(1), 653-665. doi:10.14687/jhs.v14i1.4383

the lowest. In physicians and police officers the level of depersonalization was measured at the highest levels.

In this context, it is seen that the sector in Table 9 has an effect on the emotional exhaustion.

Table 9. Differences in Emotional Exhaustion Levels of Employees by Sectors

\begin{tabular}{lclccc}
\hline & Sector & Sector & Average Difference & SE & $\mathrm{p}$ \\
\hline \multirow{3}{*}{ Emotional Exhaustion } & & Education & .5876 & .1652 & .004 \\
& \multirow{3}{*}{ Retailing } & Service & .4167 & .1638 & .084 \\
& & Industry & .3441 & .2066 & .457 \\
& & Logistics & .6653 & .2351 & .040 \\
\hline
\end{tabular}

According to the result of the Tukey test that is applied to determine the difference between the sectors, it appears that there is a significant difference $(p<.05)$ in the levels of emotional exhaustion among the employees in the retailing sector and those in the education and logistics sectors. In other words; emotional exhaustion levels of the employees in the retailing sector are higher than those working in the logistics sector by .6653 and .5876 higher than those working in the education sector.

\section{Discussion}

The research has a number of limitations. First of all, although according to the theoretical background the proper method is hierarchical regression, a comparison is made in the model of the research. Due to the fact that there is no universal measuring instrument in the measurement of the variables, the values of the variables are being compared in the study. On the other hand, different methods likewise Structural Equation Model could also be attempted by researchers. Therefore, further studies' results should be comparable.

Secondly, the research might have been far more convincing should have been included the other dimensions of burnout which are depersonalization, personal accomplishment and involvement with people. Hereby, the effects or relations between dimensions are likely to be more determined. Besides, their relations should be examined with socio-demographic factors. In this manner, the difference between groups will be explored.

Last but not least, the factors of work-life balance are cited in Turkish (Apaydin, 2011); consequently, English translation may differ in different cultural researches. It is suggested for researchers and practitioners that the results therefore need to be interpreted with caution.

Finally, there is a requirement that research findings should be supported by different researches. In different cultures, sectors and samples, the results may differ due to the fact that the survey language and characteristics of participants will change.

\section{Conclusion}

According to research findings; dimensions of work-life balance which are namely neglecting life, life is just working, work-life accordance, taking time for oneself and carrying work to home have effect on emotional exhaustion. Neglecting life, life is just working, work-life accordance and taking time for oneself dimensions have negative effect on emotional exhaustion; on the contrast, carrying work to home dimension has positive effect on emotional exhaustion. 
Tuğsal, T. (2017). The effects of socio-demographic factors and work-life balance on employees' emotional exhaustion. Journal of Human Sciences, 14(1), 653-665. doi:10.14687/jhs.v14i1.4383

According to Guest (2002, p. 267), while 55 hours of work per week reflects work-life imbalance, an employee who commits the balance between work and home may not consider this an imbalance. Therefore, the work-life balance can show a subjective characteristic. However, assuming a family member is healthy, a person is expected to be able to prioritize and manage time correctly. If $\mathrm{s} /$ he confuses priorities, it may be thought that $\mathrm{s} /$ he may be experiencing health problems, stress or burnout. Proximity to family and friends, healthy relationships and good communication are important in ensuring work-life accordance. It is important for the organizations to have policies to ensure work-life balance and to be implemented by being supported by either managers or employees in the organization.

It is thought that married employees have to work harder to make a family living; therefore, policies that provide work-life balance for married employees can be developed. If it is taken into consideration that there is a difference between married and single employees in terms of work-life balance, since married employees spend more time to their spouse and children or to the elders of the family; taking time for oneself is limited. Consequently, single employees can take more time for themselves.

\section{References}

Adriaenssens, J., De Gucht, V., \& Maes, S. (2015). Determinants and prevalence of burnout in emergency nurses: A systematic review of 25 years of research. International Journal of Nursing Studies, 52(2), 649-661.

Altay, B., Gönener, D., \& Demirkıran, C. (2010). Bir üniversite hastanesinde çalışan hemşirelerin tükenmişlik düzeyleri ve aile desteğinin etkisi. Firat Tap Dergisi, 15(1), 010-016.

Anila, K. P., \& Krishnaveni, V. (2016). Influence of family environment and work environment on work life balance among women employees. International Journal of Management Research and Reviews, 6(3), 341-347.

Apaydın, Ç. (2011). Öğretim Üyelerinin İşe Bağımlılık Düzeyi İle İş-Yaşam Dengesi ve İş-Aile Yaşam Dengesi Arasındaki İlişki. Ankara Üniversitesi, Eğitim Bilimleri Enstitüsü, Eğitim Yönetimi ve Politikası Anabilim Dal, Yaymlanmamıs Doktora Tezi.

Avanzi, L., Schuh, S. C., Fraccaroli, F., \& van Dick, R. (2015). Why does organizational identification relate to reduced employee burnout? The mediating influence of social support and collective efficacy. Work \& Stress, 29(1), 1-10. View Article: DOI: https://doi.org/10.3389/fpsyg.2016.01519

Barrett, J. L., Mazerolle, S. M., \& Eason, C. M. (2016). Exploring Senior Level Athletic Training Students' Perceptions on Burnout and Work-Life Balance. Athletic Training Education Journal, 11(2), 110-118.

Beauregard, T. A., \& Henry, L. C. (2009). Making the link between work-life balance practices and organizational performance. Human resource management review, 19(1), 9-22. View Article: DOI: http://dx.doi.org/10.1016/j.hrmr.2008.09.001

Budak, G., \& Sürgevil, O. (2005). Tükenmişlik ve tükenmişliği etkileyen örgütsel faktörlerin analizine ilişkin akademik personel üzerinde bir uygulama. DE ÜIİ BF Dergisi, 20(2), 95-108.

Chiang, F. F., Birtch, T. A., \& Kwan, H. K. (2010). The moderating roles of job control and worklife balance practices on employee stress in the hotel and catering industry. International Journal of Hospitality Management,29(1), 25-32. View Article: DOI: http://dx.doi.org/10.1016/i.ijhm.2009.04.005

Chimote, N. K., \& Srivastava, V. N. (2013). Work-life balance benefits: From the perspective of organizations and employees. IUP Journal of Management Research, 12(1), 62-73.

Clark, S. C. (2000). Work/family border theory: A new theory of work/family balance. Human relations, 53(6), 747-770. 
Tuğsal, T. (2017). The effects of socio-demographic factors and work-life balance on employees' emotional exhaustion. Journal of Human Sciences, 14(1), 653-665. doi:10.14687/jhs.v14i1.4383

Constable, J. F., \& Russell, D. W. (1986). The effect of social support and the work environment upon burnout among nurses. Journal of human stress, 12(1), 20-26.

Cordes, C. L., \& Dougherty, T. W. (1993). A review and an integration of research on job burnout. Academy of management review, 18(4), 621-656.

Crooker, K. J., Smith, F. L., \& Tabak, F. (2002). Creating work-life balance: A model of pluralism across life domains. Human Resource Development Review, 1(4), 387-419. View Article: DOI: http://dx.doi.org/10.1177/1534484302238434

Dex, S., \& Bond, S. (2005). Measuring work-life balance and its covariates. Work, Employment \& Society, 19(3), 627-637. View Article: DOI: http://dx.doi.org/10.1177/0950017005055676

Dillon, J. F., \& Tanner, G. R. (1995). Dimensions of career burnout among educators. Journalism \& Mass Communication Educator, 50(2), 4.

Ergin, C. (1992). Doktor ve hemşirelerde tükenmişlik ve Maslach tükenmişlik ölçeğinin uyarlanmas1. VII. Ulusal psikoloji kongresi bilimsel çalssmalar, 22, 25.

Etzion, D. (1984). Moderating effect of social support on the stress-burnout relationship. Journal of applied psychology, 69(4), 615. View Article: DOI: http://dx.doi.org/10.1037/0021$\underline{9010.69 .4 .615}$

Field, A. (2013). Discovering Statistics Using IBM SPSS Statistics 4th Ed. Sage Publications. London.

Friedman, S. D., Christensen, P., \& DeGroot, J. (1998). Work and life: The end of the zero-sum game. Harvard business review, 76, 119-130.

Guest, D. E. (2002). Perspectives on the study of work-life balance. Social Science Information, 41(2), 255-279.

Gülalp, B., Karcıoğlu, O., Sarı, A., \& Köseoğlu, Z. (2008). Burnout: need help?. Journal of occupational medicine and toxicology, 3(1), 1. View Article: DOI: http://dx.doi.org/10.1186/1745-6673-3$\underline{32}$

Ifeagwazi, F. C. M. (2006). The influence of marital status on self-report of symptoms of psychological burnout among nurses. OMEG A-Journal of Death and Dying, 52(4), 359-373.

İslamoğlu, A. H., Alnıaçı, Ü. (2014). Sosyal Bilimlerde Araştırma Yöntemleri. Beta Yayınları, İstanbul.

Jackson, R. A. (1993). An Analysis of Burnout among School of Pharmacy Faculty. American Journal of Pharmacentical Education, 57(1), 9-17.

Karabacak, G. (2013). İş-aile çatışmasının iş ve yaşam doyumuna etkilerinin iş stresi ve algılanan sosyal destek açısından otel personeli üzerinde incelenmesi. Doktora Tez̧i

Keeton, K., Fenner, D. E., Johnson, T. R., \& Hayward, R. A. (2007). Predictors of physician career satisfaction, work-life balance, and burnout. Obstetrics \& Gynecology, 109(4), 949-955. View Article: DOI: http://dx.doi.org/10.1097/01.AOG.0000258299.45979.37

Khezerlou, E. (2013). Teacher self-efficacy as a predictor of job burnout among Iranian and Turkish EFL teachers. Procedia-Social and Behavioral Sciences, 70, 1186-1194. View Article: DOI: http://dx.doi.org/10.1016/j.sbspro.2013.01.175

Kutsal, D., \& Bilge, F. (2012). Lise öğrencilerinin tükenmişlik ve sosyal destek düzeyleri. Eüitim ve Bilim, 37(164), 283-297.

Li, L., Ruan, H., \& Yuan, W. J. (2015). The relationship between social support and burnout among ICU nurses in Shanghai: A cross-sectional study. Chinese Nursing Research, 2(2), 45-50. View Article: DOI: http://dx.doi.org/10.1016/i.cnre.2015.04.003

MacInnes, J. (2006). Work-life balance in Europe: A response to the baby bust or reward for the baby boomers? European Societies, 8(2), 223-249. View Article: DOI: http://dx.doi.org/10.1080/14616690600644988

Maslach, C., \& Jackson, S. E. (1981). The measurement of experienced burnout. Journal of organizational behavior, 2(2), 99-113.

Maslach, C., \& Jackson, S. E. (1986). MBI: Maslach Burnout Inventory; manual research edition. University of California, Palo Alto, CA. 
Tuğsal, T. (2017). The effects of socio-demographic factors and work-life balance on employees' emotional exhaustion. Journal of Human Sciences, 14(1), 653-665. doi:10.14687/jhs.v14i1.4383

Maslach, C., Schaufeli, W. B., \& Leiter, M. P. (2001). Job burnout. Annual review of psychology, 52(1), 397-422. View Article: DOI: http://dx.doi.org/10.1146/annurev.psych.52.1.397

Maxwell, G. A., \& McDougall, M. (2004). Work-life balance: Exploring the connections between levels of influence in the UK public sector. Public Management Review, 6(3), 377-393. View Article: DOI: http://dx.doi.org/10.1080/1471903042000256547

Moeller, C., \& Chung-Yan, G. A. (2013). Effects of social support on professors' work stress. International Journal of Educational Management, 27(3), 188-202.

View Article: DOI: http://dx.doi.org/10.1108/09513541311306431

Noon, M., Blyton, P. (2007). The Realities of Work. 3rd Ed. Palgrave Macmillan. New York

Noor, N. M. (2003). Work-and family-related variables, work-family conflict and women's wellbeing: Some observations. Community, Work \& Family, 6(3), 297-319. View Article: DOI: http://dx.doi.org/10.1080/1366880032000143474

Norlund, S., Reuterwall, C., Höög, J., Lindahl, B., Janlert, U., \& Birgander, L. S. (2010). Burnout, working conditions and gender-results from the northern Sweden MONICA Study. BMC Public Health, 10(1), 1.

Novara, C., Garro, M., \& Rienzo, G. D. (2015). Coping Styles and Social Support in Emergency Workers: Family as a Resource. Romanian Journal for Multidimensional Education/Revista Romaneasca pentru Educatie Multidimensionala, 6(1).

Otacioğlu, S. G. (2008). Müzik öğretmenlerinde tükenmişlik sendromu ve etkileyen faktörler. İnönü Üniversitesi Ë̈itim Fakültesi Dergisi, 9(15).

Padmasiri, M. K. D., \& Mahalekamge, W. G. S. (2016). Impact of Demographical Factors on Work Life Balance Among Academic Staff of University of Kelaniya, Sri Lanka. Journal of Education and Vocational Research, 7(1), 54-59.

Panisoara, G., \& Serban, M. (2013). Marital status and work-life balance. Procedia-Social and Behavioral Sciences, 78, 21-25. View Article: DOI: http://dx.doi.org/10.1016/j.sbspro.2013.04.243

Pichler, F. (2009). Determinants of work-life balance: Shortcomings in the contemporary measurement of WLB in large-scale surveys. Social Indicators Research, 92(3), 449-469. View Article: DOI: http://dx.doi.org/10.1007/s11205-008-9297-5

Purvanova, R. K., \& Muros, J. P. (2010). Gender differences in burnout: A meta-analysis. Journal of Vocational Behavior, 77(2), 168-185. View Article: DOI: http://dx.doi.org/10.1016/j.jvb.2010.04.006

Ross, R. R., Altmaier, E. M., \& Russell, D. W. (1989). Job stress, social support, and burnout among counseling center staff. Journal of counseling psychology, 36(4), 464. View Article: DOI: http://dx.doi.org/10.1037/0022-0167.36.4.464

Schaufeli, W., \& Enzmann, D. (1998). The burnout companion to study and practice: A critical analysis. CRC press.

Shirom, A. (1989). Burnout in work organizations. Cooper, Cary L. (Ed); Robertson, Ivan T. (Ed). (1989). International review of industrial and organizational psychology 1989, (pp. 25-48). Oxford, England: John Wiley \& Sons, ix, 411 pp.

Smithson, J., \& Stokoe, E. H. (2005). Discourses of work-life balance: negotiating 'genderblind'terms in organizations. Gender, Work \& Organization, 12(2), 147-168.

Şencan, H. (2007). Sosyal ve Davranışsal Bilimlerde Bilimsel Araştırma. Seçkin Yayıncılık. İstanbul.

Umene-Nakano, W., Kato, T. A., Kikuchi, S., Tateno, M., Fujisawa, D., Hoshuyama, T., \& Nakamura, J. (2013). Nationwide survey of work environment, work-life balance and burnout among psychiatrists in Japan. PloS one, 8(2), e55189.

Yildırım, I. (2008). Relationships between burnout, sources of social support and sociodemographic variables. Social Behavior and Personality: an international journal, 36(5), 603-616. 